\title{
On two morphologically different cysticercoids of the genus Eurycestus (Cestoda: Dilepididae) in Artemia franciscana (Arthropoda: Artemiidae) in a hypersaline pond in Dubai, United Arab Emirates*
}

\author{
R. K. SCHUSTER
}

Central Veterinary Research Laboratory, PO Box 597, Dubai, United Arab Emirates, E-mail: r.schuster@cvrl.ae

Article info

Received January 10, 2018

Accepted March 28, 2018

\section{Summary}

During a survey on tapeworm larval stages in Artemia franciscana from an artificial pond in Dubai, United Arab Emirates, a high prevalence of Eurycestus avoceti-like cysticercoids was established. Adult male and female crustaceans showed a prevalence of 61.9 and $62.7 \%$, respectively. The intensity ranged from one to four and one to three cyst, respectively. Out of 215 examined cysticercoids, 207 specimens had morphological features matching with $E$. avoceti. The flaky structure of the surrounding capsule, the elongated shape of the cysticercoid and the larger number of hooklets on the suckers suggest that the eight further larval cestodes belonged to another species of the genus Eurycestus.

Keywords: Brine shrimps; Artemia franciscana; cysticercoids; Eurycestus; United Arab Emirates

\section{Introduction}

Brine shrimps of the genus Artemia are aquatic crustaceans that live in hypersaline environments. The genus Artemia consists of A. salina (Linnaeus, 1758), A. monica Verrill, 1869, A. urmiana Günther, 1899, A. franciscana Kellogg, 1906, A. persimilis Piccinelli \& Prosdocimi, 1968, A. sinica Cai, 1989, A. tibetiana Abatzopoulos, Zhang \& Sorgeloos, 1998 and parthenogenetic populations called A. parthenogenetica (Asem et al. 2010).

Serving as food for flamingos, waders, gulls and ducks, brine shrimps act as intermediate host for a number of avian cestodes of the Hymenolepididae family (Aploparaksis parafilum Gasowska, 1932, Brachiopodataenia gvozdevi Maksimova, 1988, Confluaria podicipina, (Szymanski, 1905), Fimbriaruioides tadornae Maksimova, 1976, Flamingolepis caroli (Parona, 1887), F. flamingo Skrjabin 1914 , F. liguloides Gervais, 1847, F. tengizi Gvozdev \& Maksimova, 1968, Hymenolepis californicus Young, 1950, Wardium fusca (Krabbe, 1869) and W. stellorae Deblock, Biguet et Capron, 1960), the Dilepididae family (Eurycestus avoceti Clark,1954, Ano- molepis averini Spassky \& Yurpalova, 1967, Anomotaenia tringae (Burt,1940) and A. microphallus (Krabbe, 1869) and the Progynotaeniidae family Gynandotaenia stammeri Fuhrmann, 1936 and Gynandrotaenia sp. Redón et al., 2015b - a so far undetermined further species of this genus) (Schuster 2018).

One of the cysticercoids that was found in numerous studies was E. avoceti (Table 1). The description of its larval stage is based only on small numbers of cysticercoids. In a recent study on the location of cestode larvae in the body of $A$. franciscana, we examined a larger number of Eurycestus cysticercoids showing the existence of two morphologically different types.

\section{Materials and Methods}

Collection site of A. franciscana

The Godolphin lakes in the Al Quoz district of Dubai are small ponds of 2.5 and 2.9 ha, respectively and were created as satellite wetland to attract wader birds. A detailed description of this habitat was given by Sivakumar et al. (2018).

\footnotetext{
${ }^{*}$ - This paper is dedicated to the $90^{\text {th }}$ birthday of my teacher, Prof. Dr. Dr. h.c. mult. Theodor Hiepe,

former director of the Parasitological Institute of the Humboldt-University of Berlin.
} 
Table 1. Frequency of Eurycestus avoceti in brine shrimps in different studies. (F: France, Es: Spain, P: Portugal, AE: United Arab Emirates)

\begin{tabular}{lllcccl}
\hline Collection site & Country & $\begin{array}{l}\text { Examined } \\
\text { host species }\end{array}$ & $\begin{array}{c}\text { Number } \\
\text { examined }\end{array}$ & $\begin{array}{c}\text { Prevalence } \\
(\%)\end{array}$ & $\begin{array}{c}\text { Average } \\
\text { intensity }\end{array}$ & Reference \\
\hline Camargue & F & Artemia sp. & 64.640 & 0.09 & $1-2$ & Robert \& Gabrion (1991) \\
Odiel Marsh & Es & A. parthenogenetica & 3,300 & 2.5 & $1-3$ & Georgiev et al. (2005) \\
Odiel Marsh & Es & A. parthenogenetica & 200 & 7.0 & - & Sanchez et al. (2006) \\
Odiel Marsh & Es & A. parthenogenetica & 100 & 17.0 & - & Sanchez et al. (2007) \\
Salinas Castro Marim & P & A. franciscana & 240 & 4.0 & 1 & Georgiev et al. (2007) \\
Odiel Marsh & Es & A. parthenogenetica & 200 & 3.0 & 1 & Georgiev et al. (2007) \\
Salinas de Nuestra & Es & A. parthenogenetica & 200 & 7.0 & 1.14 & Georgiev et al. (2007) \\
Salinas Portuguesas & Es & A. parthenogenetica & 200 & 30.0 & 1.15 & Georgiev et al. (2007) \\
Salinas de Animas & Es & A. parthenogenetica & 70 & 4.3 & 1 & Georgiev et al. (2007) \\
Salinas de St. Barbara & Es & A. franciscana & 200 & 2.0 & 1.4 & Georgiev et al. (2007) \\
Salinas de Cerillos & Es & A. salina & 200 & 8.0 & 1 & Georgiev et al. (2007) \\
La Mata Lagoon & Es & A. parthenogenetica & 195 & 2.6 & 1 & Redon et al. (2011) \\
Odiel Marsh & Es & A. parthenogenetica & 3,000 & 2.13 & 1.08 & Sanchez et al. (2013) \\
La Tapa salters & Es & A. franciscana & 949 & 2.3 & 1.09 & Georgiev et al. (2014) \\
Ebro delta & Es & A. franciscana & 9,293 & 7.6 & 1.2 & Redon et al. (2015a) \\
Ebro delta & Es & A. franciscana & 487 & 8.6 & 1.02 & Redon et al. (2015b) \\
Ebro delta & Es & A. salina & 381 & 3.9 & 1 & Redon et al. (2015b) \\
Godolphin lakes, Dubai & AE & A. franciscana & 1,840 & 4.5 & 1.1 & Sivakumar et al. (2018) \\
\hline
\end{tabular}

Examination of shrimps

Brine shrimps of the species $A$. franciscana were caught by net in the Godolphin lakes in Dubai, in May 2018 for a study of the location of cysticercoids in the body of the shrimps. Shrimps were killed in hot $70 \%$ alcohol and 300 adult specimens were randomly selected. Prior to examination, they were placed for 5 days on a slide in a drop of glycerin and were covered with a cover slip. Glycerin cleared the body of the shrimps and made the parasites visible. Examination for the presence of cysticercoids was carried out at low magnification $(40-100 x)$. Special attention was paid to cysts surrounded by a brown capsule as well as to those with a transparent capsule and suckers exhibiting hooklets. Measurements of the outer capsule were taken at a magnification of 400x. Shrimps were then dissected and cestode larvae were individually placed into a drop of glycerin. Prior to putting a cover slip, the capsule surrounding the cysticercoid was destroyed by fine preparation needles. At a magnification of $600 x$, the following parameters of each cysticercoid matching the description of the genus Eurycestus were determined: length and width of the cysticercoid, width of the scolex at the level of suckers, length and width of suckers, distribution, number and length of hooklets on suckers, length and width of the rostellum, number and length of rostellar hooks. In order to determine the exact length of sucker hooklets and rostellar hooks as well as the number of rostellar hooks most of the cysticercoids had to be squashed by pressing on the cover slip. Measurements were taken using an OLYMPUS BX51 micro-

scope connected to an OLYMPUS DP27 camera with the software OLYMPUS cellSens Dimension.

\section{Ethical Approval and/or Informed Consent}

All applicable national and institutional guidelines for the care and use of animals were followed.

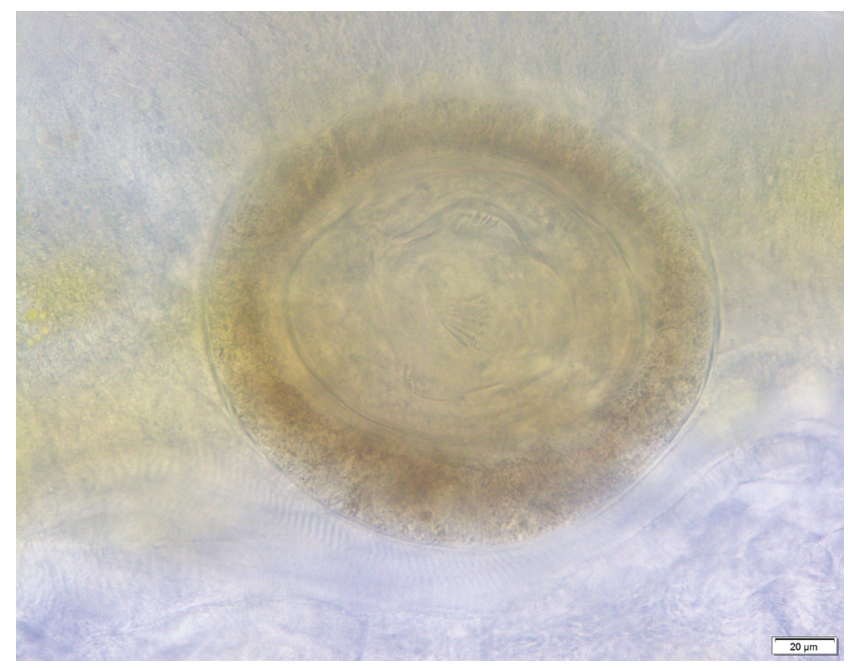

Fig. 1. Eurycestus avoceti cysticercoid surrounded by a homogenous brown capsule and found in the thorax of Artemia franciscana. 
Table 2. Prevalence and burden of Eurycestus cysticercoids in A. franciscana from Godolphin lakes of Dubai in May 2018.

\begin{tabular}{|c|c|c|c|c|c|}
\hline \multirow[t]{2}{*}{ Sex } & \multicolumn{2}{|c|}{ Number of } & \multirow{2}{*}{$\begin{array}{c}\text { Prevalence } \\
(\%)\end{array}$} & \multicolumn{2}{|c|}{ Intensity } \\
\hline & examined & parasitised & & average & range \\
\hline males & 134 & 83 & 61.94 & 1.14 & $1-4$ \\
\hline females & 166 & 104 & 62.65 & 1.15 & $1-3$ \\
\hline total & 300 & 187 & 62.33 & 1.15 & $1-4$ \\
\hline
\end{tabular}

\section{Results}

Of 300 examined $A$. franciscana, 134 were males and 166 were females. A total of 187 (= $62.33 \%$ ) of crustacean hosts harbored between one and four Eurycestus cysticercoids. There was no sex related difference in prevalence and burden (Table 2). Out of 95 Eurycestus cysticercoids in male shrimps, 93 were located in the thorax and each one in the abdomen and phyllopods. Female shrimps contained a total of 120 Eurycestus cysticercoids. Of these, 114 were detected in the thorax, four and two were found in head and abdomen, respectively.

The majority $(n=207)$ of the examined 215 cysticercoids was surrounded by a more or less homogenous, transparent to dark

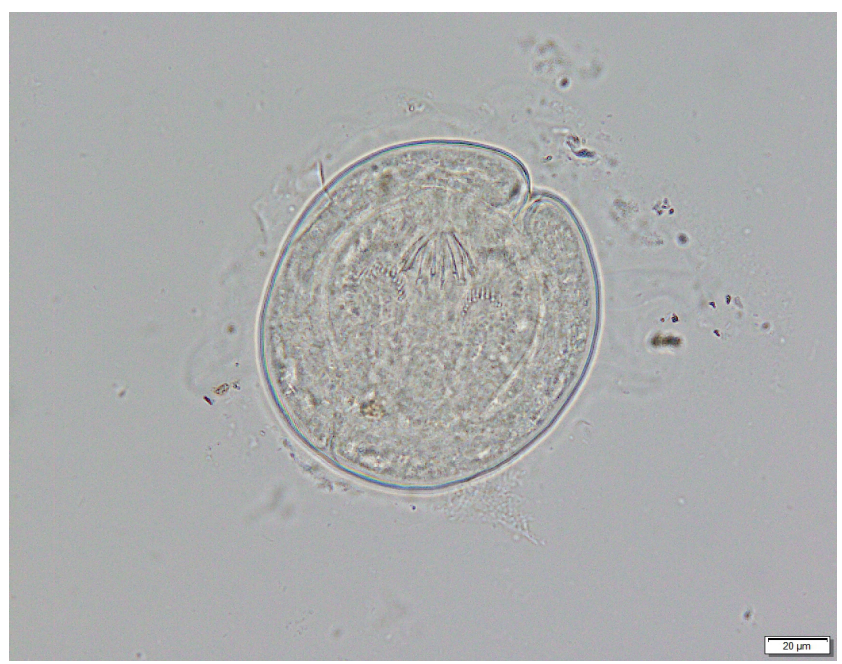

Fig. 2. Eurycestus avoceti removed from its capsule.

brown irregularly rounded capsule (Fig 1). The decapsulated cestode larval stages were heart shaped to oval round (Fig 2.) The anterior margin of the oval suckers was furnished with two layers of hooklets in total numbers between 8 and 15. In most of the cases 12 hooklets were counted (Table 3 ). Their length was $5-7 \mu \mathrm{m}$. There were 14 to 16 arcuatoid rostellar hooks arranged in two circles. Their length varied between 12 to 16 and 14 to $18 \mu \mathrm{m}$, respectively.

Eight other Eurycestus cysticercoids were surrounded by an irregularly elongated, flaky and very fragile capsule (Fig. 3). The decapsulated cysticercoids were elongated (Fig. 4) and differed from the above mentioned by a larger number of hooklets on the suckers ranging between 24 and 32 (Table 3). Sixteen arcuatoid rostellar hooks arranged in two circles measured $11-14$ and 17 $-19 \mu \mathrm{m}$, respectively.

\section{Discussion}

While previous publications reported prevalence data of Eurycestus cysticercoids in Artemia spp. between 0.09 and $30.0 \%$ (Table 1), the current study revealed an unusually high prevalence of $62.33 \%$. The reasons for this might be the small size of the habitat, a large number of birds visiting the ponds and a specific moment in time for the collection when Artemia population was in full bloom in the month of May.

The species inventory of the genus Eurycestus consists so far of three species. In addition to the description of $E$. avoceti from its final host, the American avocet (Recurvirostra americana Gmelin, 1789) by Clark (1954), Burt (1979) described two further species of the genus Eurycestus found in the same final host. E. falciformis and $E$. latissimus differed from $E$. avoceti in the shape of strobila, size of cirrus sac, number of testes and armature of the cirrus. All three descriptions were based on strobilae without scolex.

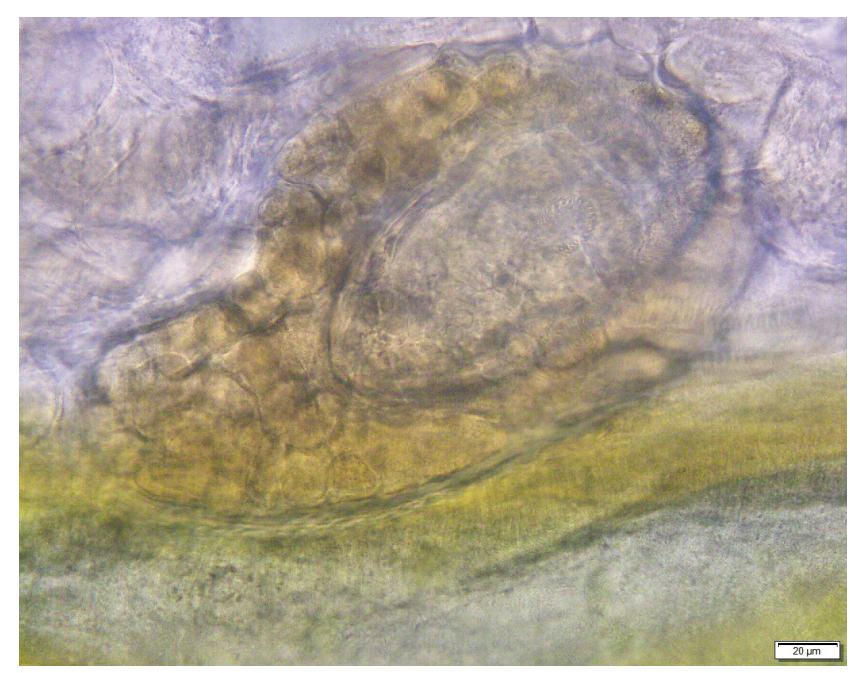

Fig. 3: Eurycestus sp. cysticercoid surrounded by a flaky capsule fragile capsule and found in the thorax of Artemia franciscana.

In addition to American and pied avocets from Nebraska and France, respectively, E. avoceti was found also in black necked stilts (Himantopus mexicanus (Müller, 1776) in Texas (Hinojus \& Canaris 1988). Maksimova (1991) mentioned greater flamingos (Phoenicopterus roseus Pallas, 1811), black-winged stilts (Himan- 


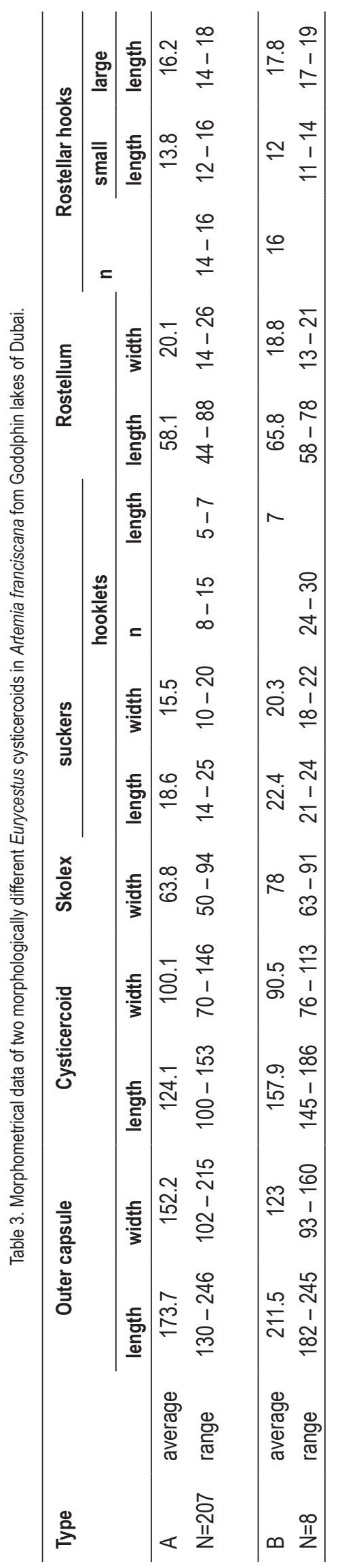




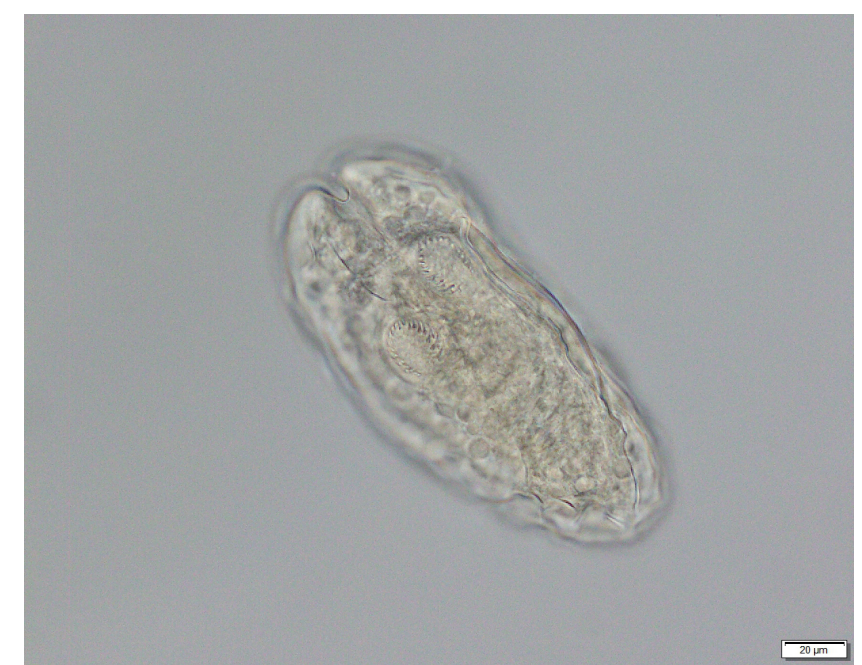

Fig. 4: Eurycestus sp. cysticercoid removed from its capsule.

topus himantopus Linnaeus, 1758) and slender-billed gulls (Chroicocephalus genei Breme, 1839) as final hosts in Kazakhstan. This wide spectrum of phylogenetically distant hosts suggests that also other birds that feed on brine shrimps might play a role in the Eurycestus life cycle.

The assignment of $E$. avoceti to the Anoplocephalidae family by Yamaguti (1959) was proven incorrect after Baer (1968) found whole cestode including scolex in avocets ${ }^{\mathrm{a}}$ in Carmargue, France and published a redescription of the species. The width of the extremely small scolex varied between only 45 and $53 \mu \mathrm{m}$ and could reach $61 \mu \mathrm{m}$ when the rostellum (52 $\mu \mathrm{m}$ long and $20 \mu \mathrm{m}$ in diameter) is retracted. There were 14 to 16 rostellar hooks in a length of 14 to $16 \mu \mathrm{m}$, arranged in two circles. Suckers bore 10 to 14 hooklets in a length of $5-6 \mu \mathrm{m}$. Baer (1968) allocated $E$. avoceti to the Dilepididae family. Based on the morphology of the scolex, Georgiev et al. (2005) considered cysticercoids found in A. parthenogenetica in the Odiel Marshes in Spain, the larval stage of $E$. avoceti. The majority of cysticercoids found in the current study (type A in Table 3) seem to belong to the same species, E. avoceti. Eight other cysticercoids in the recent study (type B, in Table 3) however, showed striking differences in the structure of the capsule, surrounding the larval stage and in the shape of the cysticercoid. A further difference was the number and the distribution of the hooklets on the suckers. Already Gabrion \& Mac Donald (1980) when examining Artemia sp. from Camarge, gave a description of an elongated cysticercoid $(170 \times 90 \mu \mathrm{m})$ suckers of which were furnished with 30 to 32 hooklets covering their anterior and lateral rims. Other parameters (number and size of rostellar hooks) did not differ significantly from above mentioned $E$. avoceti. Robert \& Gabrion (1991) examined a total of 64,604 Artemia sp. in the same habitat and found among others, a total of 59 cysticercoids matching the description by Gabrion et Mac Donald (1980). In a survey on cestode larval stages in $A$. salina from Tengiz lake in Kazakhstan, Maksimova (1991) described elongated cysticercoids measuring $140-190 \times 100-130 \mu \mathrm{m}$ being surrounded by a dark brown but very fragile capsule of $180-320 \times 150-220 \mu \mathrm{m}$ in size. The scolex measured $45-76$ x $42-71 \mu \mathrm{m}$ and had four armed suckers with 30 to 32 hooklets arranged in two rows on their anterior and lateral margins. The rostellum had a length of $50-60 \mu \mathrm{m}$ and a width of $17-22 \mu \mathrm{m}$. It was armed with 16 hooks arranged in two rows. Larger hooks measured 16 - $18 \mu \mathrm{m}$, smaller ones $10-12 \mu \mathrm{m}$. The prevalence of these cysticercoids in $A$. salina in lake Tengiz was low and varied between 0.03 and $0.5 \%$. Referring to Gabrion et Mac Donald (1980) the author believed that this was E. avoceti.

Based on the appearance of the surrounding capsule and on the morphology of the cysticercoid, it can be concluded that $A$. franciscana in the Godolphin lakes of Dubai were infected with two different Eurycestus species one of which type A can be affiliated with $E$. eurycestus. The second species (type B) comparable to those found Artemia sp. in Carmargue and in A. salina in Tengiz lake remains unnamed until the adult cestode is described.

\section{Conflict of Interest}

There is no conflict of interests.

\section{References}

Asem, A., Rastegar-Pouyani, N., De Los Ríos-Escalante P. (2010) The genus Artemia Leach, 1819 (Crustacea: Branchiopoda). I. True and false taxonomical descriptions. Lat. Am. J. Aquat. Res., 38(3): 501 - 506. DOI: 10.3856/vol38-issue3-fulltext-14

BAER J.G. (1968): Eurycestus avoceti Clark, 1954 (Cestode cyclophyllidien) parasite de l' avocette en Camargue. [Eurycestus avoceti Clark, 1954 (Cestoda; Cyclophyllidea) a parasite of the avocet in the Camargue]. Vie et Milieu, 19: 189 - 198. (In French)

BuRT, D.R.R. (1979): New cestodes of the genus Eurycestus Clark 1954 from the avocet Recurvirostra americana Gmelin 1788. Zool. J. Linn. Soc., 65: 71 - 82

CLARK, D.T. (1954): A new cyclophyllidian cestode from the avocet. J. Parasitol. 40: 340 - 346.

Gabrion, C., Mac Donald, G. (1980): Artemia sp. (Crustacé, Anostracé), hôte intermédiaire d' Eurycestus avoceti Clarc, 1954 parasite de l'avocette en Camargue. [Artemia sp. (Crustacea, Anostraca) the intermediate host of Eurycestus avoceti Clarc, 1954 a parasite of the avocet in the Camargue.] Ann. Parasitol., 55 (3): 327 - 331 (In French)

Georgiev, B.B., Angelov, A., Vasilieva, G.P., Sanchev, M.I., Hortas, F., Mutavchiev, Y., Pankov, P., Green, A.J. (2014): Larval helminths in the invasive American brine shrimp Artemia franciscana throughout its annual cycle. Acta Parasitol., 59 (3): 380 - 389. DOI: 10.2478/s11686-014-0255-X

Georgiev, B.B., Sanchez, M.I., Green, A.J., Nikolov, P.N., Vasilieva, G.P., Mavrodieva, R.S. (2005): Cestodes from Artemia parthenogenetica (Crustacea, Branchiopoda) in the Odiel Marshes, Spain: a systematic survey of cysticercoids. Acta Parasitol. 50 (2): 105 - 117

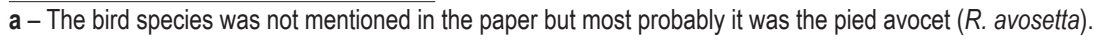


Georgiev, B.B., Sanchez M.I., Nikolov, P.N. Vasilieva, G.P., Green, A.J. (2007): Cestode parasitism in invasive and native brine shrimps (Artemia spp.) as a possible factor promoting the rapid invasion of $A$. franciscana in the Mediterranian region. Parasitol. Res. 101 (6): 1664 - 1655. DOI: 10.1007/s00436-007-0708-3

Hinojus, J.G., Canaris, A.G. (1988): Metazoon parasites of Himantopus mexicanus Muller (aves) from Southwestern Texas, with a checklist of helminth parasites from North America. J. Parasitol. 74 (2): $326-331$

Maksimova, A.P. (1991): K ekologii i biologii Eurycestus avoceti (Cestoda: Dilepididae). [On ecology and biology of Eurycestus avoceti (Cestoda: Dilepididae]. Parazitologiya 25: 73 - 76

Robert, F., Gabrion, C (1991) Cestodoses de l'avifanune camarguaise. Rôle d'Artemia (Crustacea, Anostraca) et strategies de rencontre hôte-parasite. [Cestodes of birds in Camargue. Importance of Artemia (Crustacea, Anostraca) and meeting strategies between hosts and parasites] Ann. Parasitol. Hum. Comp. 66 (5): 226 - 236 (In French)

Redon, S., Amat, F., Hontoria, F., Vasilieva, G., Nikolov, P.N., GEORGIEV, B.B. (2011): Participation of metanaulplii and juvenile individuals of Artemia parthenogenetica (Branchiopoda) in the circulation of avian cestodes. Parasitol. Res. 108(4): 905 - 912. DOI 10.1007/s00436-010-2132-3

Redón, S., Amat, F., Sánchez, M.I., Green, A.J. (2015a): Comparing cestode infections and their consequences for host fitness in two sexual branchiopods: alien Artemia franciscana and native $A$. salina from syntopic-populations. Peer J, 3:e1073; DOI: 10.7717/ peerj.1073
Redón, S., Green, A.J., Georgiev, B.B., Vasileva, G.P., Amat, F. (2015b): Influence of developmental stage and sex on infection of the American brine shrimp Artemia franciscana Kellogg, 1906 by avian cestodes in Ebro Delta salterns, Spain. Aquat. Invasions 10 (4), 415 - 423. DOI: 10.3391/ai.2015.10.4.0

Sanchez M.I., Georgiev, B.B., Green, A.J. (2007): Avian cestodes affect the behavior of their intermediate host Artemia parthenogenetica: An experimental study. Behav. Process. 74: 293 - 299. DOI: 10.1016/j.beproc.2006.11.002

Sanchez M.I., Georgiev, B.B., Nikolov, P.N. Vasilieva, G.P., Green, A.J. (2006): Red and transparent brine shrimps (Artemia parthenogenetica): a comparative study of their cestode infections. Parasitol. Res. 100 (1): 111 - 114. DOI: 10.1007/s00436-006-0248-2 Sanchez M.I., Nikolov, P.N., Georgieva, D.D., Georgiev, B.B., Vasilieva, G.P., Pankov, P., Paracuellos, M., Lafferty K.D., Green, A.J. (2013): High prevalence of cestodes in Artemia spp. throughout the annual cycle: relationship with abundance of avian final hosts. Parasitol. Res. 112 (5): 1913 - 1923. DOI: 10.1007/s00436013-3347-x.

SChuster R.K. (2018): The role of Artemia spp. (Branchiopoda: Artemiidae) as intermediate hosts for avian cestodes. Environ Anal Eco stud. 1(4). EAES.000518.2018. DOI: 10.31031/ EAES.2018.01.000518

Sivakumar, S., Hyland, K. Schuster R.K. (2018): Tapeworm larvae in Artemia franciscana (Crustacea: Anacostra) in the Goldolphin lakes of Dubai (United Arab Emirates) throughout an annual cycle. J. Helminthol. 1 - 7. DOI: 10.1017/S0022149X18000913

YAMAGUTI S. (1959) Systema helminthum 2. The cestodes of vertebrates. New York, London, Interscience Publishers, 860 pp. 